\title{
THE CORRELATION BETWEEN STUDENTS'ANXIETY AND SPEAKING SKILL AT STKIP KUSUMA NEGARA JAKARTA (A Survey Research First Semester Academic Year 2018/2019)
}

\author{
Megawati \\ English Education Program, STKIP Kusuma Negara Jakarta \\ Jalan Raya Bogor Km. 24, Cijantung Jakarta Timur 13770 \\ megawati86@stkipkusumanegara.c.id
}

\begin{abstract}
The research purpose is to know whether there is any correlation between students' anxiety and speaking skill at STKIP Kusuma Negara Jakarta. This research is quantitative correlational research. The research sample consists of 25 students. The data of the students' anxiety were collected by using the questionaire which was adopted from foreign Language Classroom Anxiety Scale of Horwitz, Horwitz and Cope at FLCAS, while the data of students'speaking skill were collected by using speaking test. This research has two variables, independent variable which variable students' anxiety and dependent variable consists of students' speaking skill. The researcher uses SPSS program, before doing the analysis the data normality was tested by using KolmogorfSmirnov test to see if the population was distributed normal. The research result concluded that there is significant correlation between variable $(\mathrm{X})$ students' anxiety and variable (Y) speaking skill. Sig. (2-tailed) is $0.001<0.05$. It means that students who have higher speaking skill, they were influenced by anxiety. The value of correlation coefficient is $-0.629<0.5$. It means that there is negative correlation between students' anxiety and speaking skill. If the students'anxiety is high so speaking skill is low and if the students'anxiety is low so speaking skill is high.
\end{abstract}

Key words: correlation, students' anxiety, speaking skill

\begin{abstract}
ABSTRAK
Penelitian ini bertujuan untuk mengetahui apakah terdapat hubungan antara kecemasan siswa dengan kemampuan berbicara pada STKIP Kusuma Negara. Penelitian ini menggunakan metode kuantitatif dan design korelasi. Sampel dalam penelitian tersebut berjumlah 25 mahasiswa. Data yang berupa kecemasan siswa dikumpulkan menggunakan angket yang diambi dari Horwitz, Horwitz dan Cope (FLCAS). Sementara data kemampuan berbicara berupa test speaking. Dalam penelitian ini, peneliti menggunakan dua variable. Variabel bebas yaitu kecemasan siswa dan variable terikat yaitu kemampuan berbicara. Peneliti menggunakan program SPSS. Untuk mengetahui apakah data tersebut normal maka digunakan Kolmogorf Smirnov. Hasil dalam penelitian tersebut disimpulkan bahwa terdapat korelasi yang signifikan antara kecemasan siswa dan kemampuan berbicara. Dapat dilihat sig. (2-tailed) 0.001<0.05, yang berarti bahwa kemampuan berbicara yang tinggi dipengaruhi oleh kecemasan. Taraf koefisien korelasi $-0.629<0.5$, yang menunjukan bahwa terdapat hubungan negative antara kecemasan siswa dan kemampuan berbicara. Maksudnya adalah bila
\end{abstract}


kecemasan tinggi maka kemampuan berbicara rendah dan apabila kecemasan rendah maka kemampuan berbicaranya tinggi.

Kata kunci: hubungan, kecemasan siswa, kemampuan berbicara

\section{INTRODUCTION}

Human communicates with language. By using language people can share their information to others. In communication, it happen feed back between someone who gives and someone receives those informations. Speaking is verbal communication. It can produce sound which speaks by speaker. Then the people hear what the speaker says. Speaking is one of the skills in English. We can know performance their ability in english with speaking and writing because both of the skills is productive skills. Speaking is one of the lesson in English Education . In learning speaking, students are be able to master their ability in speaking. Teacher have to master speaking very well. Students' fist semester have the problem in speaking. Students usual speak in Bahasa Indonesia when they learn English.

Students difficult in speaking English because they lackness vocabulary and shy to speak in front of the people. In case students fell uncomfortable psyhological states such as nervousess, trembling and anxiety. Anxiety is a feeling that someone uncertain or hesitant with their ability, also anxiety called negative feeling someone that described low self confidence so that they can't do maximal work in their life. When learn foreign language, people can feel anxiety when they speak target language such as learn English language. Someone with high anxiety can get negative effect especially when they practice speak in front of the people. They get low understand because they feel nervousess when they faced difficult words and they did't want to ask with the teacher.
According to Brown (2000:141), "Anxiety is associated with feelings of uneasiness, frustration, self-doubt, apprehensions, or worry". It means that anxiety in negative feeling which happen to someone when they get work or new something. They feel low confident to do what they have do to finish their homework. Scovel (1978) defined anxiety as an affective emotional state, uncomfortable in which one discerns danger, feels powerless, and experiences tension in the face of an expected danger. It means that anxiety expresses feel uncomfortable to something that happen. This situation makes tension abnormal and also danger. According Hurd (2007) states that language anxiety has become central to any examination of factors contributing to learning process and learner achievement. It means that there are some factors which support in learning foreign language. When people learn English language, they get anxiety expression because it's first time they have to achieve what are the goals in learning process. The objective goal should be reach by the learner.

Speaking is the performance skills in English. When students learn English, they have to practice and also produce words, sentence by speech. They have to know what is the meaning of the words that they are spoken in order that the listener can understand what the speaker means. According to Bashir, et. al. (2011:38), "Speaking is productive skill in the oral mode". It is like the other skills, is more complicated that it seems at first and involves more than just pronouncing words. It means that speaking is not only produce how the pronouncing words but also how the words and sentence can understand with 
the speaker. Based on Brown and Yule (1983:27) Speaking is to express the needs, request, service, etc. It means that by speaking, someone can express what they want to the people. They can ask something what they needed also give information what they known. Brown (2004) also divides some aspects in speaking which are measured by using the rating scores in speaking assessment. It can be seen in the tables below.

Table 1

The Rating Scores in Speaking Assessment

\begin{tabular}{|c|c|c|}
\hline Aspect & Score & \\
\hline \multirow{5}{*}{ Grammar } & 1 & $\begin{array}{l}\text { Speaker can be understood by a native speaker used to dealing with } \\
\text { foreigners attempting to speak his language }\end{array}$ \\
\hline & 2 & $\begin{array}{l}\text { Can usually handle elementary constructions quite accurately but } \\
\text { does not have thorough }\end{array}$ \\
\hline & 3 & $\begin{array}{l}\text { Able to speak the language with sufficient structural accuracy to } \\
\text { participate effectively in most formal and informal conversations on } \\
\text { practical, social, and professional topics. }\end{array}$ \\
\hline & 4 & $\begin{array}{l}\text { Able to use the language accurately on all levels normally pertinent } \\
\text { to professional needs. Errors in grammar are quite rare. }\end{array}$ \\
\hline & 5 & Equivalent to that of an educated native speaker. \\
\hline \multirow{5}{*}{ Vocabulary } & 1 & $\begin{array}{l}\text { Speaking vocabulary inadequate to express anything but the most } \\
\text { elementary needs. }\end{array}$ \\
\hline & 2 & $\begin{array}{l}\text { Has speaking vocabulary sufficient to express himself simply with. } \\
\text { some circumlocutions. }\end{array}$ \\
\hline & 3 & $\begin{array}{l}\text { Able to speak the language with sufficient vocabulary to participate } \\
\text { effectively in most formal and informal conversations on practical, } \\
\text { social, and professional topics. }\end{array}$ \\
\hline & 4 & $\begin{array}{l}\text { Can understand and participate in any conversation within the range } \\
\text { of his experience with a high degree of precision of vocabulary. }\end{array}$ \\
\hline & 5 & $\begin{array}{l}\text { Speech on all levels is fully accepted by educated native speakers in } \\
\text { all its features including breadth of vocabulary and idioms, } \\
\text { colloquialisms, and pertinent cultural references. }\end{array}$ \\
\hline \multirow{5}{*}{ Comprehension } & 1 & $\begin{array}{l}\text { Can understand simple questions and statements if delivered with } \\
\text { slowed speech, repetition, or paraphrase. }\end{array}$ \\
\hline & 2 & Can get the gist of most conversations of non-technical subjects. \\
\hline & 3 & Comprehension is quite complete at a normal rate of speech. \\
\hline & 4 & Can understand any conversation within the range of his experience. \\
\hline & 5 & Equivalent to that of an educated native speaker. \\
\hline \multirow{5}{*}{ Fluency } & 1 & $\begin{array}{l}\text { No specific fluency description. Refer to other four language areas } \\
\text { for implied level of fluency }\end{array}$ \\
\hline & 2 & $\begin{array}{l}\text { Can handle with confidence but not with facility most social } \\
\text { situations, including introductions and casual conversations about } \\
\text { current events, as well as work, family, and autobiographical } \\
\text { information. }\end{array}$ \\
\hline & 3 & $\begin{array}{l}\text { Can discuss particular interests of competence with reasonable ease. } \\
\text { Rarely has to grope for words }\end{array}$ \\
\hline & 4 & $\begin{array}{l}\text { Can participate in any conversation within the range of this } \\
\text { experience -with a high degree of fluency. }\end{array}$ \\
\hline & 5 & $\begin{array}{l}\text { Has complete fluency in the language such that his speech is fully } \\
\text { accepted by educated native speakers. }\end{array}$ \\
\hline \multirow{3}{*}{ Pronunciation } & 1 & $\begin{array}{l}\text { Errors in pronunciation are frequent' but can be understood by a } \\
\text { native speaker used to dealing with foreigners attempting to speak } \\
\text { his language. }\end{array}$ \\
\hline & 2 & Accent is intelligible though Often quite faulty. \\
\hline & 3 & $\begin{array}{l}\text { Errors never interfere with understanding and rarely disturb the } \\
\text { native speaker. Accent may be obviously foreign. }\end{array}$ \\
\hline
\end{tabular}


$4 \quad$ Errors in pronunciation are quite rare.

5 Equivalent to and fully accepted by educated native speakers.

\section{METHOD}

The researcher used quantitative research and the design was correlational research. This research is conducted to know the correlation between two variables that is the independent variable or variable $(\mathrm{X})$ which is students' anxiety and the dependent variable or variable (Y) which is students' speaking skill. In this researcher took one of the two classes was first semester English Education in academic year 2018/2019. This is the sampling technique which is done in random without being determined. The students were conducted 25 students.

In this research, the researcher use questionnaires to collect data from the students. The researcher used Foreign Language Classroom Anxiety
Scale (FLCAS) by Horwitz, Horwitz and Cope (1986) to know the level of students' anxiety in the classroom. The answer from the questionnaire is strongly agree, agree, neither agree, disagree, or strongly agree. If positive statement, it gives score 5,4,3,2, and $1 \mathrm{fi}$ negative statement. Creswell (2012:386) states that "Closed-ended questions in surveys, the researcher gives question and response options for the participant". Also Creswell (2012:167) states that "Likert scale illustrates a scale with theoretically equal intervals among responses".

\section{RESULTS AND DISCUSSION}

In Speaking test, students was given 3 minutes for describing someone by orally. In questionaire, students was given 15 questions.

Table 2

Descriptive Statistic

Descriptive Statistics

\begin{tabular}{|l|r|r|r|r|r|r|r|r|r|}
\hline & \multicolumn{1}{|c|}{$\mathrm{N}$} & Minimum & Maximum & \multicolumn{1}{c|}{ Mean } & \multicolumn{1}{|c|}{ Std. Deviation } & \multicolumn{2}{|c|}{ Skewness } & \multicolumn{2}{c|}{ Kurtosis } \\
\cline { 2 - 10 } & Statistic & Statistic & Statistic & Statistic & Statistic & Statistic & Std. Error & Statistic & Std. Error \\
\hline Students'Anxiety & 25 & 50 & 82 & 62.16 & 8.567 & .755 & .464 & .475 & .902 \\
Speaking Skill & 25 & 55 & 85 & 72.20 & 9.101 & -.440 & .464 & -.961 & .902 \\
Valid N (listwise) & 25 & & & & & & & & \\
\hline
\end{tabular}

From the table above, there are 25 scores both of speaking test and students' anxiety questionnaire. The minimum score of speaking is 55 and 50 for students' anxiety. The maximum score of speaking is 85 and 82 for students' anxiety. The mean of speaking is 72.20 and 62.16 for students' anxiety.

Table 3

One Sample Kolmogorov Smirnov Test

One-Sample Kolmogorov-Smirnov Test

\begin{tabular}{|c|c|c|c|}
\hline & & $\begin{array}{c}\text { Students'Anxi } \\
\text { ety }\end{array}$ & Speaking Skill \\
\hline $\mathrm{N}$ & & 25 & 25 \\
\hline \multirow[t]{2}{*}{ Normal Parameters ${ }^{a \cdot b}$} & Mean & 62.16 & 72.20 \\
\hline & Std. Deviation & 8.567 & 9.101 \\
\hline \multirow{3}{*}{ Most Extreme Differences } & Absolute & .126 & .221 \\
\hline & Positive & .126 & .150 \\
\hline & Negative & -.078 & -.221 \\
\hline Kolmogorov-Smirnov Z & & .632 & 1.104 \\
\hline Asymp. Sig. (2-tailed) & & .819 & .175 \\
\hline
\end{tabular}


From the table above, mean of speaking skill is 72.20 and 62.16 for students' anxiety, standard deviation of speaking 9.101 and 8.567 for students' anxiety. $\mathrm{N}$ is the number of sample is 25 students, significant number of speaking is 0.175 and 0.819 for students' anxiety with the significant value 0.05 . It means that Sig. (2-tailed) >0.05; $\mathrm{H}_{0}$ was accepted. It was concluded that the data distribution was normal.
$\mathrm{H}_{0}$ : if Sig. (2-tailed) $>0.05$, the data distribution was normal

$\mathrm{H} 1$ : if Sig. (2-tailed) $<0.05$, the data distribution was not normal;

After testing the normality value, the researcher finds out the correlation between students' anxiety on speaking skill.

Table 4

Correlation

\begin{tabular}{|ll|r|r|}
\multicolumn{4}{|c|}{ Correlations } \\
\hline & $\begin{array}{c}\text { Students'Anxi } \\
\text { ety }\end{array}$ & Speaking Skill \\
\hline Students'Anxiety & Pearson Correlation & 1 & $-.629^{\prime \prime}$ \\
& Sig. (2-tailed) & & .001 \\
& $\mathrm{~N}$ & 25 & 25 \\
\hline Speaking Skill & Pearson Correlation & $-.629^{\prime \prime}$ & 1 \\
& Sig. (2-tailed) & .001 & \\
& N & 25 & 25 \\
\hline
\end{tabular}

**. Correlation is significant at the 0.01 level (2-tailed).

Based on the table above, it can be seen that the value of correlation coefficient is -.629, it means the Pearson product moment coefficient correlation is (-) negative correlation between students' anxiety and speaking skill because from the table above It can be known score of significant 0.001 , in order words, the alternative hypothesis $\left(\mathrm{H}_{\mathrm{a}}\right)$ is accepted and Null hypothesis $\left(\mathrm{H}_{0}\right)$ is rejected. If Sig. (2-tailed) is $0.001<$ 0.05 , It means that there is correlation between students' anxiety and speaking skill.

The purpose of this research is to determine the correlation between students' anxiety and speaking skill. There is negative correlation between students' anxiety and speaking skill. It means that the value of correlation coefficient is $-0.629<0.5$. The negative (-) shown that if students' anxiety is high so speaking skill is low and if students' anxiety is low so speaking skill is high.
If. Sig (2-tailed) is $>0.05$, there is no correlation;

if . Sig (2-tailed) is $<0.05$, there is significant correlation.

From this research, It can be seen that Sig. (2-tailed) is $0.001<0.05$, it means that there is significant correlation between students' anxiety and speaking skill. $\mathrm{H}_{\mathrm{a}}$ is accepted, means there is correlation between students' anxiety and speaking skill and $\mathrm{H}_{0}$ is rejected, means there is no correlation between students' anxiety and speaking skill.

\section{CONCLUSION}

Based on the discussion above and the result of the research, the researcher uses correlation research of Pearson product moment correlation coefficient. This research use two variable, variable $(\mathrm{X})$ is students' anxiety and variable (Y) is speaking skill. This sample is 25 students first semester STKIP Kusuma Negara. This research 
conducted to know is there any correlation between students' anxiety and speaking skill. After this research, It can be known that there is significant correlation between variable (X) and variable (Y). Sig. (2-tailed) is $0.001<$ 0.05 . It means that students who have higher speaking skill, they influence with anxiety. If students feel confident, comfortable and no doubt to speak in front of the others, they can reach good English achievement. Because they can minimize their anxiety. They can solve what they must do to decreasing those negative feeling. Those feeling can make bad situation whenever they learn foreign language especially learn speaking English. They must regard their friends as to be partner for discussing and make talkative situation when the learn speaking. Students and teacher should encourage good environment to build English daily in every day in the school.

\section{REFERENCES}

Creswell, J. W. (2012). Educational Research: Planning, Conducting, and Evaluating Quantitative and Qualitative Research. Boston: Pearson Education, Inc.

Brown, G., \& Yule, G. (1983). Teaching the Spoken Language: An
Approach Based on the Analyses of Conventional English. Australia: Cambridge University Press.

Brown, H. D. (2000). Principles of Language Teaching and Learning. While plains, NY: Longman.

$$
\text { (2004). Language }
$$

Assessment: Principles and Classroom Practices. New York: Pearson Education.

Hurd. (2007). Anxiety and non-anxiety in a distance language learning environment: the distance factor as a modifying influence. System, 35(4), 489

Horwitz, E. K., Horwitz, M. B., \& Cope, J. (1986). Foreign language classroom anxiety. The Modern Language Journal, 70 (2), 125132. Doi: $10.2307 / 327317$

Bashir, et. al. (2011). Factor effecting students' English speaking skills. British Journal of Arts and Social Sciences, 2(1), 38.

Scovel, T. (1978). The effect of effect on foreign language classroom anxiety scale. System, 41(2), 462471. https://doi.org/10.1016/j.system.2 013.04 .001 